\title{
TATA KELOLA ENERGI TERBARUKAN DI SEKTOR KETENAGLISTRIKAN DALAM KERANGKA PEMBANGUNAN HUKUM NASIONAL
}

\section{(RENEWABLE ENERGY GOVERNANCE IN THE ELECTRICITY SECTOR IN THE NATIONAL LAW DEVELOPMENT FRAME WORK)}

\author{
Oleh: Nunuk Febriananingsih \\ Pusat Analisa dan Evaluasi Hukum Nasional \\ Badan Pembinaan Hukum Nasional, Kementerian Hukum dan HAM RI \\ Email: febrianasdalh1@gmail.com
}

\begin{abstract}
ABSTRAK
Listrik merupakan sumber daya energi yang strategis dan sangat penting bagi hajat hidup rakyat banyak. Pemerintah sudah berusaha untuk membebaskan Indonesia dari krisis energi listrik dan berupaya mencari alternatif penggunaan energi baru dan terbarukan (EBT). Pemerintah telah berkomitmen bahwa EBT akan terus dikembangkan untuk menjamin ketahanan energi di Indonesia serta memenuhi permintaan listrik yang kian bertambah. Pemerintah menetapkan target $23 \%$ porsi energi bersih dalam bauran energi nasional di tahun 2025 dan 31\% pada tahun 2030 melalui Kebijakan Energi Nasional (KEN) dan Rencana Umum Energi Nasional (RUEN). Pemerintah telah menerbitkan Peraturan Menteri Energi dan Sumber Daya Mineral Nomor 50 Tahun 2017 tentang Pemanfaatan Sumber Energi Terbarukan Untuk Penyediaan Tenaga Listrik (selanjutnya disebut Permen ESDM 50/2017) sebagaimana diubah Peraturan Menteri Energi dan Sumber Daya mineral Nomor 53 Tahun 2018 tentang Perubahan Atas Peraturan Menteri Energi dan Sumber Daya Mineral Nomor 50 Tahun 2017 tentang Pemanfaatan Sumber Energi Terbarukan untuk Penyediaan Tenaga Listrik (Permen ESDM 53/2018) yang masih mengalami kendala dalam implementasinya. Beberapa persoalan tersebut diantaranya adalah bagaimana tata kelola EBT di Indonesia, faktor penyebab pertumbuhan pengelolaan EBT yang belum optimal, kebijakan peraturan perundang-undangan terkait EBT di sektor ketenagalistrikan yang perlu dievaluasi. Kajian ini menggunakanpendekatan deskriptif analitis dengan menggunakan metode yuridis normatif yaitu menganalisas norma hukum yang terdapat dalam peraturan perundang-undangan dan implementasinya di lapangan. Hasil penelitian didapatkan bahwa saat ini perkembangan EBT di Indonesia masih menghadapi banyak tantangan yang tercermin dari lambatnya pertumbuhan kontribusi EBT terhadap pasokan energi nasional. Faktor lambannya pertumbuhan EBT disebabkan beberapa hal antara lain Permen 50/2017 mengalami banyak kendala dalam implementasinya, baik dari sisi pembiayaan, kepastian hukum, teknologi dan keadilan.
\end{abstract}

Kata Kunci: Ketenagalistrikan, Energi Baru Terbarukan, EBT, BOOT.

\section{ABSTRACT}

Electricity is a strategic energy for many people. The government has been tried to Indonesia's freedom from crisis of electricity and looking for alternative of renewable energy. The government has committed that EBT will be developed to ensure energy security in Indonesia. 
The government has set a target of 23\% for energy mix in 2025 and 31\% stated on National Energy Policy (KEN) and General Plan of National Energy. Indonesia has Ministry of ESDM Regulation Number 50 Year 2017 on Utilization of Renewable Energy Sources for Electric Powe Supply (hereinafter reffered to as Permen 50/2017) as amended by Regulation of the Minister of Energy and Mineral Resources Number 53 Year 2018 concerning Amendment to the Regulation of the Minister of Energy and Mineral Resources Number 50 Year 2017 concerning Utilization of Renewable Energy Resources for Electric Power Supply (hereinafter reffered to as Permen 53/2018) which is still experiencing abstacles in its implementation. Some of these problems include how about renewable energy management in Indonesia, causative factor the growth of EBT management that has not been optimal, regulatory policies related to EBT in the electricity sector that need to be evaluated and future steps in order to realize legal development in the EBT sector according to the target of RUEN. This study using descriptive analytical approach with using juridical normative method, analyzing of legal norm in regulatin and its implementation. The result of study showing that EBT implementation in Indonesia facing many challenges. The slowgoing factor of EBT growth is due to several thing, among others, that Minister Regulation Number 50 Year 2017 facing many obstacles in its implementation, both in term of financing, legal certeanty, technology and justice.

Keywords: Electricity, Renewable Energy, EBT, BOOT.

\section{A. Pendahuluan}

Bangsa Indonesia saat ini sudah menapaki kaki tahun ketiga pembangunan jangka panjang. Apakah kita akan berhasil menuju visi Bangsa 20 tahun yaitu Indonesia yang mandiri, maju, adil dan makmur? Visi ini mengarah pada pencapaian tujuan nasional, seperti tertuang dalam Pembukaan UUD, dan harus dapat diukur untuk dapat mengetahui tingkat kemandirian, kemajuan, keadilan dan kemakmuran yang kita capai. Untuk mencapai visi tersebut pembangunan hukum diarahkan untuk mendukung terwujudnya Sistem Hukum
Nasional yang mantap bersumber pada Pancasila dan Undang-Undang Dasar Negara Republik Indonesia 1945, yang mencakup pembangunan materi hukum, struktur hukum, dan budaya hukum termasuk pembangunan hukum sektor energi. ${ }^{1}$ Sektor energi merupakan salah satu agenda prioritas dalam RPJMN 20152019. Agenda ini masuk dalam agenda Nawacita yang ke-7 dalam rangka mewujudkan kemandirian ekonomi dengan menggerakkan sektor-sektor strategis ekonomi domestik. Pasal 33 ayat (2) UUDNRI Tahun 1945 menyatakan bahwa “Cabang-cabang produksi yang penting bagi

1 Badan Pembangunan Hukum Nasional, Dokumen Pembangunan Hukum Nasional Tahun 2016, BPHN, Jakarta, 2016, hlm. 17 
Negara dan yang menguasai hajat hidup orang banyak dikuasai oleh Negara". Dari sinilah pijakan dari makna kedaulatan energi harus dibangun. Agenda pembangunan bidang dalam Buku II Lampiran RPJMN 2015-2019 juga mengusung isu strategis yang selaras yaitu bidang pengelolaan sumber daya alam dan lingkungan hidup. Khusus yang menyangkut isu sektor energi adalah: (1) penguatan pasokan, bauran dan efisiensi konsumsi energi. $^{2}$

Energi merupakan sektor penting bagi pembangunan Indonesia. Tidak hanya dalam soal pemasukan kepada Devisa Negara, tetapi juga menentukan dalam perkembangan kemajuan peradaban bangsa Indonesia. Energi merupakan sumber daya alam penting dan strategis yang menguasai hajat hidup orang banyak sehingga menjadi kewenangan Negara untuk menguasainya dan dipergunakan untuk sebesar-besarnya kemakmuran rakyat sesuai dengan Pasal 33 UndangUndang Dasar Negara Republik Indonesia Tahun $1945 .^{3}$
Tata kelola energi meliputi penyediaan, pemanfaatan dan pengusahaan harus dilakukan secara berkelanjutan. Dalam mengelola sektor energi untuk jangka panjang perlu dilakukan perencanaan yang terintegrasi pada pengembangan sumber daya energi agar dapat menjamin ketersediaan energi jangka panjang. Indonesia adalah Negara yang memiliki keanekaragaman sumber daya alam yang berlimpah, termasuk sumber daya energi. Peranan Indonesia di bidang energi sangat besar, misalnya Indonesia adalah salah satu eksportir batubara dan LNG (Liquified Naturan Gas) terbesar di dunia. Kekayaan tersebut sebenarnya merupakan modal untuk menjadi Negara besar. Namun demikian, sampai saat ini permintaan energi di Indonesia masih didominasi oleh energi yang tidak terbarukan yaitu (unrenewable energy) yaitu energi fosil. Pada tahun 2013, energi fosil menyumbang 94.3\% dari total keseluruhan kebutuhan energi, sementara sisanya yaitu $5,7 \%$ dipenuhi dari Energi Baru dan Terbarukan (selanjutnya disbut EBT). ${ }^{4}$

Ibid., hlm. 259-261

3 Badan Pembinaan Hukum Nasional, Analisis dan Evaluasi Hukum Dalam Rangka Kedaulatan Energi, Laporan Akhir Tim Pokja, Jakarta, 2016, hlm. 1.

4 Muhammad AS Hikam: Ketahanan Energi Indonesia 2015-2025 Tantangan dan Harapan (Jakarta: CV. Rumah Buku, 2014), hlm. 8. 
Pasokan energi diproyeksikan akan tumbuh rata-rata sebesar 5,2\% per tahun pada kurun waktu 2012-2025. Bauran energi pada tahun 2012 didominasi oleh minyak bumi (39\%), diikuti batubara (22\%), dan gas bumi (17\%). Mengingat cadangan energi fosil Indonesia terbatas jika dibandingkan dengan cadangan dunia, dimana minyak hanya $0,20 \%$, gas $1,60 \%$ dan batubara $1,10 \%$ maka peranan minyak dan gas diperkirakan akan menurun dan digantikan oleh peningkatan pasokan batubara dan energi baru terbarukan (EBT) sehingga dirasa perlu segera mengoptimalkan pemanfaatan sumber EBT. ${ }^{5}$

Indonesia memiliki 6 (enam) sumber daya EBT, yakni energi air, surya, angin, arus laut, bio energi dan panas bumi. Potensi Indonesia untuk mengolah atau memanfaatkan sumber EBT tersebut sangatlah mungkin sebab potensi EBT cukup besar. Akan tetapi hingga saat ini pemanfaatannya masih sangat kecil dan belum maksimal dimanfaatkan. Menyadari hal tersebut pemerintah Indonesia perlahan mulai merubah paradigma terhadap EBT dengan cara tidak lagi memandang bahwa EBT ini merupakan energi alternatif melainkan memandang EBT sebagai energi yang penting. Secara nyata, hal ini terlihat dalam Rencana Umum Energi Nasional (RUEN) pemerintah, dimana dalam RUEN ini pemerintah telah menargetkan EBT dari 11,9\% menjadi 23\% hingga tahun 2025, dan diharapkan pada tahun 2020 sudah mencapai 17-18\%. Untuk mencapai hal ini tidaklah mudah, perlu disusun strategi dalam pengelolaan energi, diantaranya melalui pembangunan pembangkit listrik dengan EBT, salah satunya adalah pembangkit listrik tanaga bayu (PLTB) yang di bangun di Sidrap Sulawesi Selatan, yang diresmikan Presiden Jokowi pada tanggal 2 Juni 2018. Dengan memiliki 30 (tigapuluh) wind turbin generator (WTG) atau kincir angin, PLTB Sidrap akan menghasilkan listrik sebesar 75 Mega Watt (MW) dan diproyeksikan akan mampu mengaliri listrik kepada 70.000 pelanggan di wilayah Sulawesi Selatan. PLTB Sidrap merupakan pembangkit tenaga bayu pertama dan terbesar di Indonesia

Agus Sugiyono, Permasalahan dan Kebijakan Energi Saat Ini, dalam Prosiding Peluncuran Buku Outlook Energi Indonesia 2014 \& Seminar Bersama BPPT dan BKK-PII, Jakarta, Tahun 2015, hlm. 10 
yang memanfaatkan lahan kurang lebih 100 hektar. ${ }^{6}$

Dalam perkembangannya, berbagai masalah dalam menjaga keberlanjutan pasokan energi dalam memenuhi kebutuhan energi untuk jangka panjang bisa saja terjadi. Dalam pembangunan berkelanjutan (Sustainable Development Goals) memasukkan energi agar seluruh negara dapat memastikan bahwa akses energi haruslah terjangkau, andal, modern dan berkelanjutan bagi semua pihak sebab energi berperan sebagai faktor penting dalam pembangunan berkelanjutan. Saat ini perkembangan EBT di Indonesia masih menghadapi banyak tantangan yang tercermin dari lambatnya pertumbuhan kontribusi EBT terhadap pasokan energi nasional, bahkan pada tahun 2014 hingga 2016 saja hanya bergeser dari 6\% hingga 7\%. Faktor lambannya pertumbuhan EBT disebabkan beberapa hal antara lain tantangan pembiayaan, tantangan teknologi dan tantangan dari sisi kebijakan pemerintah dalam rangka tata kelola EBT yang seringkali efektivitas peraturannya menimbulkan berbagai persoalan. ${ }^{7}$

Berdasarkan latar belakang diatas, dalam artikel ini penulis akan membahas terkait 3 (tiga) hal yaitu: Bagaimana kebijakan tata kelola EBT di Indonesia? Faktor-faktor yang menyebabkan pertumbuhan pengelolaan EBT sektor ketenagalistrikan belum optimal? Dan terkahirBagaimana evaluasi kebijakan peraturan perundang-undangan terkait EBT di sektor ketenagalistrikan?

\section{B. Metode Penelitian}

Berdasarkan latar belakang dan permasalahan diatas, kajian ini dilakukan dengan menggunakan pendekatan yuridis normatif. Penelitian normatif adalah penelitian yang dilakukan dengan cara meneliti bahan pustaka atau data sekunder. Pemikiran normatif didasarkan pada penelitian yang mencakup (1) asas-asas hukum, (2) sistematik hukum, (3) taraf sinkronisasi vertikal dan horisontal, (4) perbandingan hukum, (5) sejarah hukum. ${ }^{8}$

6 https://ekonomi.kompas.com/read/2018/01/16/090100826/melihat-pltb-sidrap-pembangkittenaga-angin-pertama-di-indonesia, diakses pada tanggal 20 september 2019

7 https://ekonomi.kompas.com/read/2017/11/17/083000026/bappenas--perkembangan-energiterbarukan-hadapi-banyak-tantangan

8 Soerjono Soekanto dan Sri Mamudji, Peranan dan Penggunaan Perpustakaan di Dalam Penelitian Hukum, Jakarta: Pusat Dokumentasi Hukum Fakultas Hukum Universitas Indonesia, 1979, hlm. 15. 
Penulis juga melakukan analisis terhadap beberapa peraturan perundang-undangan terkait sektor ketenagalistrikan dan menganalisisnya dikaitkan dengan implementasinya di lapangan.

\section{Pembahasan}

\section{Kebijakan Tata Kelola EBT di Indonesia}

Sumber daya energi sebagai kekayaan alam merupakan anugerah Tuhan Yang Maha Esa kepada rakyat dan bangsa Indonesia. Selain itu, sumber daya energi merupakan sumber daya alam yang strategis dan sangat penting bagi hajat hidup rakyat banyak terutama dalam peningkatan kegiatan ekonomi, kesempatan kerja, dan ketahanan nasional, oleh karenanya maka sumber daya energi harus dikuasai Negara dan dipergunakan bagi sebesar-besarnya kemakmuran rakyat sebagaimana diamanatkan dalam Pasal 33 Undangundang Dasar Negara Republik Indonesia Tahun 1945. Mengingat arti penting sumber daya energi, Pemerintah perlu menyusun rencana pengelolaan energi untuk memenuhi kebutuhan energi nasional yang berdasarkan kebijakan pengelolaan energi jangka panjang. Oleh karena itu pada tanggal 10 Agustus 2007 pemerintah mengeluarkan UndangUndang Nomor 30 Tahun 2007 tentang Energi (selanjutnya disebut UU Energi). ${ }^{9}$

Pengaturan masalah EBT diatur dalam Pasal 4 ayat (2) dan (3) UU Energi dimana dikatakan bahwa:

Pasal 4 Ayat (2) "Sumber daya energi baru dan sumber daya energi terbarukan diatur oleh Negara dan dimanfaatkan untuk sebesar-besar kemakmuran rakyat";

Pasal 4 Ayat (3) "Penguasaan dan pengaturan sumber daya energi oleh Negara diselenggarakan oleh Pemerintah sesuai dengan ketentuan peraturan perundangundangan".

Makna "dikuasai oleh Negara" dalam Pasal 4 Ayat (2) dan (3) tersebut diatas akan dijelaskan pada sub bab selanjutnya.

UU Energi mengamanatkan pemerintah untuk menyusun Kebijakan Energi Nasional (KEN). KEN adalah kebijakan pengelolaan energi yang berdasarkan prinsip keadilan,

9 Indonesia, Undang-Undang Nomor 30 Tahun 2007 tentang energi, diundangkan di Jakarta pada tanggal 10 Agustus 2007, LNRI Tahun 2007 Nomor 96, TLNRI Nomor 4746, penjelasan umum. 
berkelanjutan, dan berwawasan lingkungan guna terciptanya kemandirian energi dan ketahanan energi nasional. Oleh karena itu pada tanggal 17 Oktober 2014, pemerintah mengeluarkan Peraturan Pemerintah Nomor 79 Tahun 2014 tentang Kebijkaan Energi Nasional (selanjutnya disebut PP 79/2014). Dasar penerbitan PP ini adalah Pasal 11 ayat (2) UU Energi. KEN ini merupakan pedoman untuk memberi arah pengelolaan energi nasional guna mewujudkan kemandirian energi dan ketahanan energi nasional untuk mendukung pembangunan nasional berkelanjutan.

Kebijakan energi nasional terdiri dari kebijakan utama dan kebijakan pendukung yang dilaksanakan untuk periode tahun 2014 sampai dengan 2050. Kebijakan utama meliputi ketersediaan energi untuk kebutuhan nasional, prioritas pengembangan energi, pemanfaatan sumber daya energi nasional, dan cadangan energi nasional. Sedangkan untuk kebijakan pendukung meliputi konservasi energi, konservasi sumber daya energi dan diversifikasi energi; lingkungan hidup dan keselamatan; harga, subsidi dan insentif energi; infrastruktur dan akses untuk masyarakat terhadap energi dan industri; penelitian, pengembangan, dan penerapan teknologi energi; dan kelembagaan dan pendanaan. ${ }^{10}$

Sasaran penyediaan energi primer, kapasitas pembangkit, dan pemanfaatan listrik pada tahun 2025 dan 2050 ditunjukkan dalam Table 1, sedangkan target bauran energi primer yang optimal ditunjukkan pada gambar 1 sebagai berikut: ${ }^{11}$

Tabel 1. Sasaran penyediaan dan pemanfaatan energi

\begin{tabular}{|l|c|c|c|}
\hline & Satuan & $\mathbf{2 0 2 5}$ & $\mathbf{2 0 5 0}$ \\
\hline Energi Primer & MTOE & 400 & 1.000 \\
\hline Energi Primer per Kapita & TOE & 1,4 & 3,2 \\
\hline Kapasitas Pembangkit Listrik & GW & 115 & 430 \\
\hline Listrik per Kapita & kWh & 2.500 & 7.000 \\
\hline
\end{tabular}

10 Ibid., Pasal 3

11 Agus Sugiyono, Op., Cit, hlm. 13. 


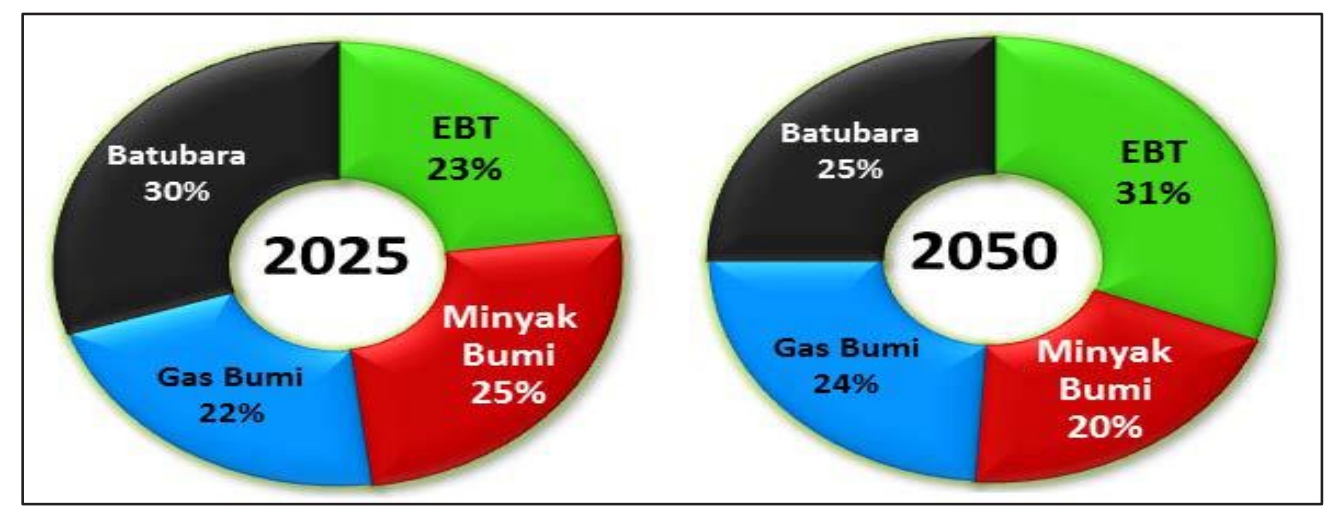

Gambar 1. Sasaran Bauran Energi Nasional

Kebijakan peningkatan peran EBT dalam bauran energi nasional seperti yang digambarkan pada gambar 1 bukan tanpa alasan yang kuat. Sebagaimana telah disinggung diatas bahwa Indonesia kaya akan sumber EBT, seperti air terjun, panas bumi, sinar matahari, angin, dan arus laut meskipun sampai saat ini belum termanfaatkan dengan maksimal. Pemanfaatan EBT memang lebih cocok untuk pembangkit tenaga listrik. Sayangnya pembangkit listrik Indonesia masih lebih banyak mengandalkan energi fosil. Rendahnya pemanfaatan dan pengembangan EBT pada pembangkit listrik terjadi karena berbagai permasalahan, antara lain: (a) belum maksimalnya pelaksanaan kebijakan harga, (b) ketidakjelasan subsidi EBT pada sisi pembeli loff- taker), (c) regulasi yang belum dapat menarik investasi, (d) belum adanya insentif pemanfaatan EBT, (e) minimnya ketersediaan instrumen pembiayaan yang sesuai dengan kebutuhan investasi, (f) proses perizinan yang rumit dan memakan waktu yang lama, dan (g) permasalahan lahan dan tata ruang.

Selanjutnya, secara lebih teknis KEN menurunkan Rencana Umum Energi Nasional (selanjutnya disebut RUEN) dan Rencana Umum Ketenagalistrikan Nasional (selanjutnya disebut RUKN) serta diturunkan lagi yang lebih rinci dalam Rencana Usaha Penyediaan Tenaga Listrik (selanjutnya disebut RUPTL). RUEN merupakan kebijakan Pemerintah Pusat mengenai rencana pengelolaan energi tingkat nasional yang menjadi penjabaran dan rencana 
pelaksanaan Kebijakan Energi Nasional yang bersifat lintas sektor untuk mencapai sasaran Kebijakan Energi Nasional. RUEN ditetapkan dalam Peraturan Presiden Nomor 22 Tahun 2017 (selanjutnya disebut Perpres RUEN) yang ditandatangani Presiden Penetapan RUEN ini merupakan pelaksanaan pasal 12 ayat 2 dan pasal 17 ayat 1 Undang-Undang Energi. Pasal 12 ayat 2 tersebut mengamanatkan Dewan Energi Nasional bertugas : (a) merancang dan merumuskan kebijakan energi nasional untuk ditetapkan oleh Pemerintah dengan persetujuan DPR, (b) menetapkan rencana umum energi nasional, (c) menetapkan langkahlangkah penanggulangan kondisi krisis dan darurat energi, serta (d) mengawasi pelaksanaan kebijakan di bidang energi yang bersifat lintas sektoral.

Dalam lampiran 1 Perpres RUEN dikatakan bahwa arah kebijakan energi ke depan berpedoman pada paradigma bahwa sumber daya energi tidak lagi dijadikan sebagai komoditas ekspor semata, tetapi sebagai modal pembangunan nasional. Tujuannya untuk : (a) mewujudkan kemandirian pengelolaan energi, (b) menjamin ketersediaan energi dan terpenuhinya kebutuhan sumber energi dalam negeri, (c) mengoptimalkan pengelolaan sumber daya energi secara terpadu dan berkelanjutan, (d) meningkatkan efisiensi pemanfaatan energi, (e) menjamin akses yang adil dan merata terhadap energi, pengembangan kemampuan teknologi, industri energi dan jasa energi dalam negeri, (f) menciptakan lapangan kerja dan terkendalinya dampak perubahan iklim dan terjaganya fungsi lingkungan hidup.

RUEN diturunkan pada aturan yang lebih rinci dalam RUKL. RUKL merupakan kebijakan umum di bidang ketenagalistrikan yang terpadu mencakup antara lain, perkiraan kebutuhan dan penyediaan tenaga listrik, kebijakan investasi dan pendanaan, kebijakan pemanfaatan sumber energi primer serta energi baru terbarukan untuk pembangkit tenaga listrik. RUKN ditetapkan sebagai acuan dalam pembangunan dan pengembangan sektor ketenagalistrikan di masa yang akan datang bagi Pemerintah, Pemerintah Daeerah, 
Pemegang Kuasa Usaha

Ketenagalistrikan (PKUK) dan

Pemegang Izin Usaha Ketenagalistrikan untuk Kepentingan Umum (PIUKU). Peranan RUKN akan semakin penting dengan adanya perubahan lingkungan strategis baik dalam lingkup lokal, nasional, regional maupun global. Disamping itu partisipasi swasta pada sektor ketenagalistrikan diharapkan semakin meningkat, sehingga RUKN ini dapat memperjelas dan membakukan penentuan proyek yang akan dilaksanakan oleh PKUK maupun yang akan dikerjasamakan dengan pihak lain. Hal ini sebagaimana diatur dalam keputusan Menteri ESDM Nomor 2682 K/21/MEM/2008 tentang Rencana Umum Ketenagalistrikan Nasional. RUKN diturunkan lagi yang lebih rinci pada RUPTL. Salah satu kebijakan dalam RUPTL 2018-2027 adalah pemerintah menurunkan total rencana pembangunan pembangkit dari 78.000 megawatt jadi 56.024 megawatt. Hal ini merupakan angka realistis menurut pemerintah.

\section{Faktor-Faktor Penyebab Pertumbuhan} Pengelolaan EBT di Sektor Ketenagalistrikan Belum Optimal
Pemerintah telah berkomitmen bahwa EBT akan terus dikembangkan untuk menjamin ketahanan energi di Indonesia serta memenuhi permintaan listrik yang kian bertambah. Bahkan Pemerintah Indonesia menetapkan target yang lumayan tinggi yaitu $23 \%$ porsi energi bersih dalam bauran energi nasional di tahun 2025 dan 31\% pada tahun 2030 melalui Kebijakan Energi Nasional (KEN) dan Rencana Umum Energi Nasional (RUEN). Untuk mencapai target tersebut, diperlukan tata kelola sektor EBT yang diwujudkan dengan penerapan kebijakan dan penataan regulasi yang tepat serta partisipasi dari semua pihak, baik pemerintah, swasta, maupun masyarakat.

Sebagaimana telah diuraikan pada sub bab sebelumnya bahwa sumber daya energi merupakan kekayaan alam yang tunduk kepada ketentuan Pasal 33 UUD NRI Tahun 1945. Pengaturan masalah EBT diatur dalam Pasal 4 UU Energi. Makna dikuasai dan diatur oleh Negara masih menimbulkan polemik dan multitafsir dalam implementasinya. Sebab rezim "dikuasi oleh Negara" dan "diatur oleh Negara" akan 


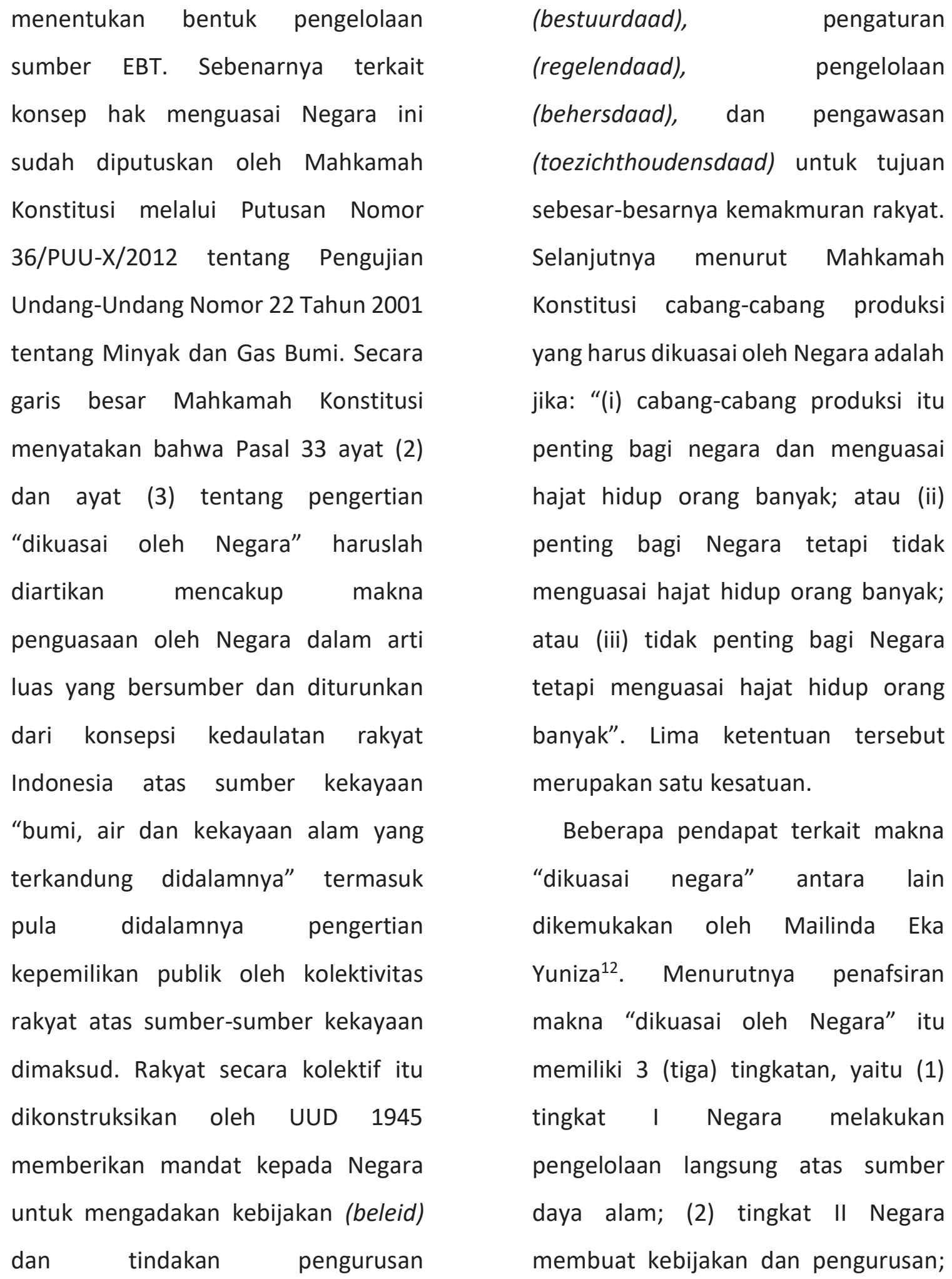

12 Mailinda Eka Yuniza, Kajian Distribusi Kewenangan Dalam Tata Kelola Sektor Energi Terbarukan, disampaikan pada Diskusi Terbatas yang diselenggarakan oleh World Resources Indonesia (WRI, di Jakarta, tanggal 18 April 2018, hlm. 10. 
(3) tingkat III Negara melaksanakan fungsi pengaturan dan pengawasan (dengan kata lain diatur). Menurutnya, apabila rezimnya hanya diatur maka kewenangan pemerintah lebih sempit dan implikasinya untuk pemanfaatan dan pengembangan EBT tidak harus ada pengelolaan langsung oleh Pemerintah karena kewajiban itu hanya akan muncul apabila Negara mempunyai kewenangan secara langsung melakukan pengelolaan Sumber Daya Alam. Namun dalam kaitannya dengan sektor ketenagalistrikan, sebagaimana diatur dalam Pasal 33 ayat (2) UUD 1945 dikatakan bahwa Ketenagalistrikan adalah cabang produksi yang penting bagi Negara dan menguasai hajat hidup orang banyak, sehingga harus dikuasai oleh Negara.

Hal ini sejalan dengan putusan MK Nomor 001-021-022/PUU-I/2003 terkait pengujian UU No. 20 Tahun 2002 tentang Ketenagalistrikan. Mahkamah Konstitusi berpendapat bahwa tenaga listrik hingga saat ini masih merupakan cabang produksi yang penting bagi Negara dan menguasasi hajat hidup orang banyak, sehingga oleh karenanya menurut Pasal 33 ayat (2) UUD 1945 harus tetap dikuasai oleh Negara, dalam arti harus dikelola oleh Negara melalui perusahaan Negara yang didanai oleh pemerintah (Negara) atau dengan kemitraan bersama swasta nasional atau asing yang menyertakan dana pinjaman dari dalam dan luar negeri atau dengan melibatkan modal swasta nasional/asing dengan sistem kemitraan yang baik dan saling menguntungkan. Hal ini berarti bahwa hanya BUMN yang boleh mengelola usaha tenaga listrik, sedangkan perusahaan swasta nasional atau asing hanya ikut serta apabila diajak kerjasama oleh BUMN, baik kemitraan, penyertaan saham, pinjaman modal dan lain-lain.

Persoalannya adalah apakah yang dimaksud dengan perusahaan Negara pengelola tenaga listrik hanyalah BUMN, dalam hal ini PLN, ataukah bisa dibagi dengan perusahaan Negara yang lain, bahkan dengan perusahaan daerah (BUMD) sesuai dengan semangat otonomi daerah? Mahkamah berpendapat, jika PLN memang masih mampu dan bisa lebih 
efisien, tidak ada salahnya jika tugas itu tetap diberikan kepada PLN, tetapi jika tidak, dapat juga berbagi tugas dengan BUMN lainnya atau BUMD dan PLN sebagai "holding company". 13

Oleh karena PLN merupakan satusatunya perusahaan distributor listrik untuk kepentingan umum. Hal ini berimplikasi pada perbedaan rezim UU Energi dan UU Ketenagalistrikan yang masih menimbulkan multitafsir/ standar ganda dalam kewenangan pengelolaan EBT antara Pemerintah, BUMN, ataupun swasta. Salah satu dampaknya adalah adanya ketidakpastian bagi para pelaku usaha. Berbagai persoalan terkait pengaturan EBT akan dijelaskan di sub bahasan berikutnya. Dengan konstruksi hukum yang demikian, tafsir MK dalam makna “dikuasai Negara” Pasal 33 UUD 1945 secara lebih detail dijelaskan dalam gambar sebagai berikut:

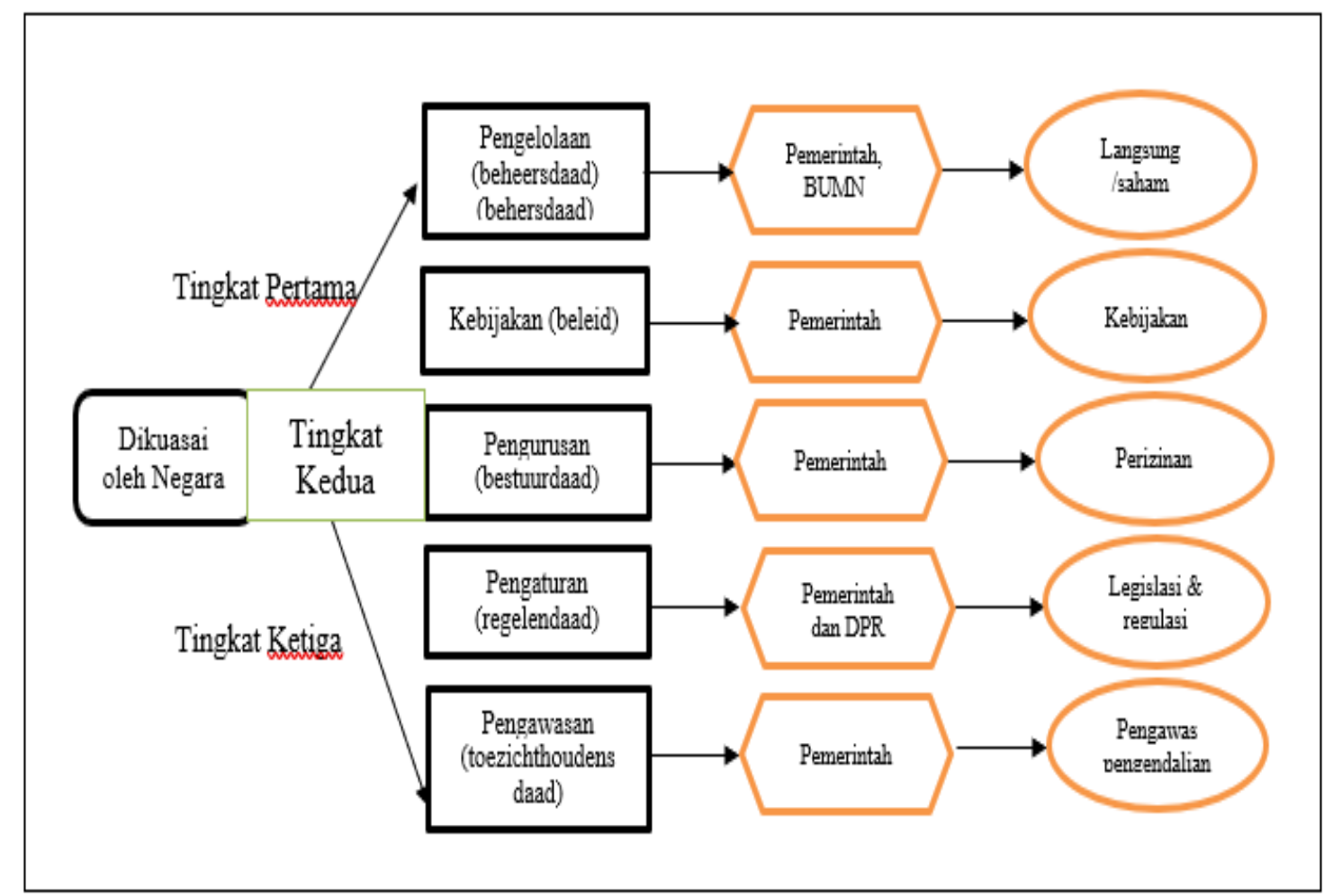

Gambar 2: Makna “Dikuasai Negara”

13 Mahkamah Konstitusi, Putusan MK Nomor 001-021-022/PUU-I/2003 terkait pengujian UU No 20 Tahun 2002 tentang Ketenagalistrikan, Jakarta, 1 Desember 2004, hlm. 348. 
Gambar diatas dapat dijelaskan sebagaimana berikut. Saat ini yang terjadi adalah terdapat 3 (tiga) distribusi kewenangan Pemerintah dalam tata kelola sektor EBT: ${ }^{14}$

(1) Tingkat Pertama, Untuk sumber daya EBT yang merupakan pengolahan lebih lanjut dari bahan bakar fosil, panas bumi, nuklir, dan hidro skala besar, maka EBT tersebut dikuasai oleh Pemerintah;

(2) Tingkat Kedua, untuk sumber daya EBT yang tidak berasal dari sumber-sumber diatas, seperti surya, hidro skala kecil, angin, biomasa, maka Pemerintah hanya berperan sebagai legislator atau regulator untuk EBT;

(3) Tingkat Ketiga, seluruh sumber daya EBT yang dimanfaatkan untuk ketenagalistrikan dikuasai oleh Pemerintah, meskipun sumber daya EBT tersebut berasal dari sumber daya EBT yang hanya diatur oleh Pemerintah, seperti surya, angin, biomassa;

Pendapat lainnya adalah dari Prof Jimly Asshidiqie. Sebagaimana kita ketahui bahwa Pustusan Mahkamah Konstitusi adalah pertama dan terakhir (first and final). Terkait makna "dikuasai oleh Negara" adalah sudah tepat penguasaan sesuai Pasal 33 UUD bukan pemilikan. Penguasaan memiliki makna lebih luas. Hal ini untuk mengantisipasi perkembangan global dunia. Saat ini Perusahaan Multi Nasional itu sudah merambah ke seluruh dunia, berkembang dan sangat kuat. Dunia usaha adalah instrumen kemajuan suatu bangsa. Oleh Karena itu harus ada intermediate structure dalam dunia usaha terhadap Negara. Sebab Negara harus tetap mempunyai kedaulatan, harus tetap berkuasa demi kepentingan nasional. Negara menentukan untuk mengatur. Banyak pihak mempertentangkan antara konsep penguasaan, pemilikan, pengurusan dalam Pasal 33. Penguasaan adalah konsep total seluruhnya. Penguasaan Negara sebagaimana dimaksud dalam Putusan MK yang terdiri dari 5 (lima) konsep frasa yaitu kebijakan, pengurusan, pengaturan, pengelolaan dan pengawasan adalah kesemuanya.

14 Ibid., hlm. 13 
Pelaksanaan terhadap 1 frasa misalnya melaksanakan pengaturan, maka itu juga sebagai bentuk penguasaan Negara. Untuk urusan-urusannya ini perlu ditentukan oleh Pemerintah, misalnya EBT sebagaimana diatur dalam Pasal 4 ayat (1) itu merupakan penegasan bahwa bahan bakar fosil, panas bumi, nuklir, dan hidro skala besar adalah hal yang penting dan menguasai hajat hidup orang banyak menurut Negara, maka harus dikuasai oleh Negara. Kemudian Pasal 4 ayat (2) itu seolah-olah dipertentangkan dengan Pasal 4 ayat (1), yaitu mempertentangkan antara menguasai dan mengatur, padahal seharusnya tidak perlu dipertentangkan. Bahwa setelah dikuasai sebagaimana Pasal 4 ayat(1) masih harus dijabarkan dalam aturan berikutnya bagaimana pengaturannya bagaimana, pengurusannya bagaimana, pengawasannya bagaimana. Inilah yang perlu diluruskan terhadap Pasal 4 UU Energi ini.

Terkait monopoli PLN, tidak bisa disamakan seperti dunia usaha.
Monopoli hanya relevan dalam dunia usaha. Negara memang menguasai namun bukan dalam konteks seperti monopoli dalam dunia usaha. BUMN adalah instrumen kekuasaan Negara (agent of development) untuk menggerakkan roda ekonomi nasional bukan instrumen untuk mencari keuntungan semata. Sebagai badan hukum, bahan usaha (private company) nya Negara, dia dimaksudkan menjadi instrumennya Negara untuk menjalankan fungsi pengusahaan, BUMN tersebut bisa menjadi pioneer di usaha tertentu, nanti ketika sudah besar bisa saja dilepas ke swasta (privatisasi). Maksud dari dilaksanakan BUMN adalah untuk mendorong pembangunan ekonomi nasional.

Sejalan dengan pendapat Prof Jimly Asshidiqie adalah pendapat Prof Maria Soemardjono, ${ }^{15}$ terkait konsep "dikuasai oleh Negara" ada 3 (tiga) hal kenapa dikuasai oleh Negara yaitu: (1) Penting bagi negara dan menguasai hajat hidup orang banyak; (2) Tidak penting bagi Negara tapi menguasai

15 Maria Soemardjono, Rapat Tim Pakar Bidang SDALH, diselenggarakan di Jakarta pada tanggal 2 Agustus 2018. 
hajat hidup orang banyak; (3) Penting bagi Negara tapi tidak menguasai hajat hidup orang banyak. Ketiga hal ini termasuk dalam konsep dikuasai oleh Negara. Artinya, jika Negara sudah merasa tidak mampu, maka Negara akan minta bantuan pihak lain dalam hal ini bisa swasta, tetapi kontrol tetap ada pada Negara. Jadi jika dalam Pasal 4 UU Energi mengatakan diatur oleh Negara itu salah. Sebab, Hak menguasai Negara itu terdiri dari 5 (lima) frasa yaitu membuat kebijakan, mengelola, mengatur, mengurus dan mengawasi. Tidak bisa dipisah satu per satu, mengatur itu juga termasuk menguasai, jika dipertentangkan justru akan bertentangan dengan Konstitusi. Oleh karena itu Pasal 4 UU Nomor 30 Tahun 2007 seharusnya direvisi karena bertentangan dengan konstitusi UU Pasal 33 UUD NRI Tahun 1945 sebab Bumi, Air, Kekayaan Alam dikuasai oleh Negara. Oleh karena itu agar ketentuan Pasal 4 ayat (2) agar dapat harmonis dengan tafsir MK atas Hak dikuasai Negara, maka sebaiknya ketentuan untuk EBT bukan "diatur" namun "dikuasai oleh Negara", sebab makna "dikuasai oleh Negara" sudah terdapat elemen "diatur". Perlu dirumuskan definisi atau ditambahkan dalam penjelasan terkait makna "diatur" sebagaimana di maksud dalam Pasal 4 ayat (2). Hal ini penting karena pelaku usaha butuh kepastian berusaha di sektor EBT. ${ }^{16}$

Dari beberapa pendapat tersebut diatas, penulis sepakat dengan apa yang disampaikan Prof Jimly Ashidiqie dan juga Prof Maria Soemardjono, bahwa makna "dikuasai oleh Negara" tidak perlu dipertentangan kata per kata, sebab konsepnya adalah menyeluruh.

3. Evaluasi Kebijakan Peraturan Perundang-undangan terkait EBT di Sektor Ketenagalistrikan

Sebagaimana dibahas sebelumnya terakit RUKN, dimana RUKN ditetapkan sebagai acuan dalam pembangunan dan pengembangan sektor ketenagalistrikan di masa yang akan datang bagi Pemerintah, Pemerintah Daerah, Pemegang Kuasa Usaha Ketenagalistrikan (PKUK) dan

16 Badan Pembinaan Hukum Nasional, Laporan Analisis dan Evaluasi Hukum Terkait Ketenagalistrikan, Jakarta, 2018, hlm. 47-49. 
Pemegang Izin Usaha Ketenagalistrikan untuk Kepentingan Umum (PIUKU) dan juga RUPTL dimana salah satu kebijakan dalam RUPTL 2018-2027 adalah pemerintah menurunkan total rencana pembangunan pembangkit dari 78.000 megawatt jadi 56.024 megawatt maka diterbitkanlah Peraturan Menteri Nomor 50 Tahun 2017 tentang Pemanfaatan Sumber Energi Terbarukan Untuk Penyediaan Tenaga Listrik (selanjutnya disebut Permen ESDM 50/2017) sebagaimana diubah Peraturan Menteri Energi dan Sumber Daya mineral Nomor 53 Tahun 2018 tentang Perubahan Atas Peraturan Menteri Energi dan Sumber Daya Mineral Nomor 50 Tahun 2017 tentang Pemanfaatan Sumber Energi Terbarukan untuk Penyediaan Tenaga Listrik (Permen ESDM 53/2018). Permen 53/2018 merupakan perubahan beberapa Pasal yang intinya adalah menambahkan ketentuan mengenai pembelian tenaga listrik oleh PT PLN dari pembangkit listrik yang memanfaatkan energi bahan bakar nabati cair, sehingga pasal-pasal lainnya dalam Permen ESDM 50/2017 tetap berlaku.
Dasar diterbitkannya Permen ESDM $50 / 2017$ ini adalah untuk mempercepat pengembangan energi terbarukan untuk kepentingan ketenagalistrikan nasional, sehingga perlu diatur kembali ketentuan mengenai mekanisme dan harga pembelian tenaga listrik oleh PT Perusahaan Listrik Negara (Persero) yang memanfaatkan sumber energi terbarukan. Permen ESDM 50/2017 ini menggantikan Permen Nomor 12 Tahun 2017 tentang Pemanfaatan Sumber Energi Terbarukan untuk Penyediaan Tenaga Listrik sebagaimana telah diubah dengan Pemen ESDM Nomor 43 Tahun 2017 tentang Perubahan atas Permen ESDM Nomor 12 Tahun 2017 tentang Pemanfaatan Sumber Energi Terbarukan untuk Penyediaan Tenaga Listrik yang dicabut dan dinyatakan tidak berlaku lagi. Permen ESDM 50/2017 ini menjadi pedoman bagi PT PLN (Persero) dalam melakukan pembelian tenaga listrik dari pembangkit tenaga listrik yang memanfaatkan sumber ET. Sumber ET tersebut meliputi sinar matahari, angin, tenaga air, biomassa, biogas, 
sampah kota, panas bumi, dan gerakan

dan perbedaan suhu lapisan laut. ${ }^{17}$

Pokok-pokok substansi dari Permen
ESDM 50/2017 sebagaimana diuraikan dalam tabel sebagai berikut:

Tabel 2. Pokok-Pokok Substansi Permen ESDM 50/2017

\begin{tabular}{|c|c|c|}
\hline NO & POKOK BAHASAN & SUBSTANSI PASAL \\
\hline 1. & Jenis Pembangkit & $\begin{array}{l}\text { PLT Surya Fotovoltaik, PLT Bayu, PLT Air, PLT Biomassa, } \\
\text { PLT Biogas, PLT Sampah, PLT Panas Bumi dan PLTA Laut } \\
\text { (Pasal } 3 \text { ayat 3) }\end{array}$ \\
\hline 2. & Pelaksanaan Pembelian Tenaga Listrik & $\begin{array}{l}\text { - Pemilihan Langsung Berdasarkan Kuota Kapasitas } \\
\text { (Untuk PLTS Fotovoltaik dan PLTB) } \\
\text { - Pemilihan Langsung (Untuk PLTA, PLTBM, PLTBg dan } \\
\text { PLTA Laut) } \\
\text { - Sesuai Ketentuan PUU (Untuk PLTSa dan PLTP) }\end{array}$ \\
\hline 3. & Pola Kerjasama & Build, Own, Operate and Transfer (BOOT) \\
\hline 4. & Persetujuan Harga & $\begin{array}{l}\text { Pembelian tenaga listrik wajib mendapatkan Persetujuan } \\
\text { Menteri }\end{array}$ \\
\hline 5. & $\begin{array}{l}\text { Standar Perjanjian Jual Beli Tenaga } \\
\text { Listrik (PJBL) }\end{array}$ & $\begin{array}{l}\text { PT PLN (Persero wajib menyusun dan Mempublikasikan } \\
\text { Standar Dokumen Pengadaan, Standar PJBL, dan Juknis } \\
\text { Pelaksanaan Pemilihan Langsung }\end{array}$ \\
\hline
\end{tabular}

Dalam Permen ESDM 53/2018, terdapat perubahan Pasal 1, Pasal 3 dan sisipan Pasal 12A yang pada intinya mengatir tentang pembelian tenaga listrik yang memanfaatkan energi bahan bakar nabati cair dimana hal ini belum diatur dalam Permen ESDM 50/2017. Dalam implementasinya, Permen 50/2017 ini memiliki berbagai persoalan antara lain:
1. Terkait Skema Penentuan Biaya Pokok Penjualan Litrik Energi Terbarukan. Permen 50/2017 mengatur Biaya Pokok Penyediaan (BPP) dalam pembelian listrik dari Sumber ET. ${ }^{18}$ Harga pembelian tenaga listrik untuk PLTS Fotovoltatik, PLTB, PLTBm, PLTBg, PLTA Laut menggunakan mekanisme yang saling

17 Indonesia Permen ESDM Nomor 50 Tahun 2017 tentang Pemanfaatan Sumber Energi Terbarukan Untuk Penyediaan Tenaga Listrik, diundangkan di Jakarta pada tanggal 8 Agustus 2017, Berita Negara RI Atahun 2017 Nomor 1107.

18 Ibid., Pasal 5-20. 


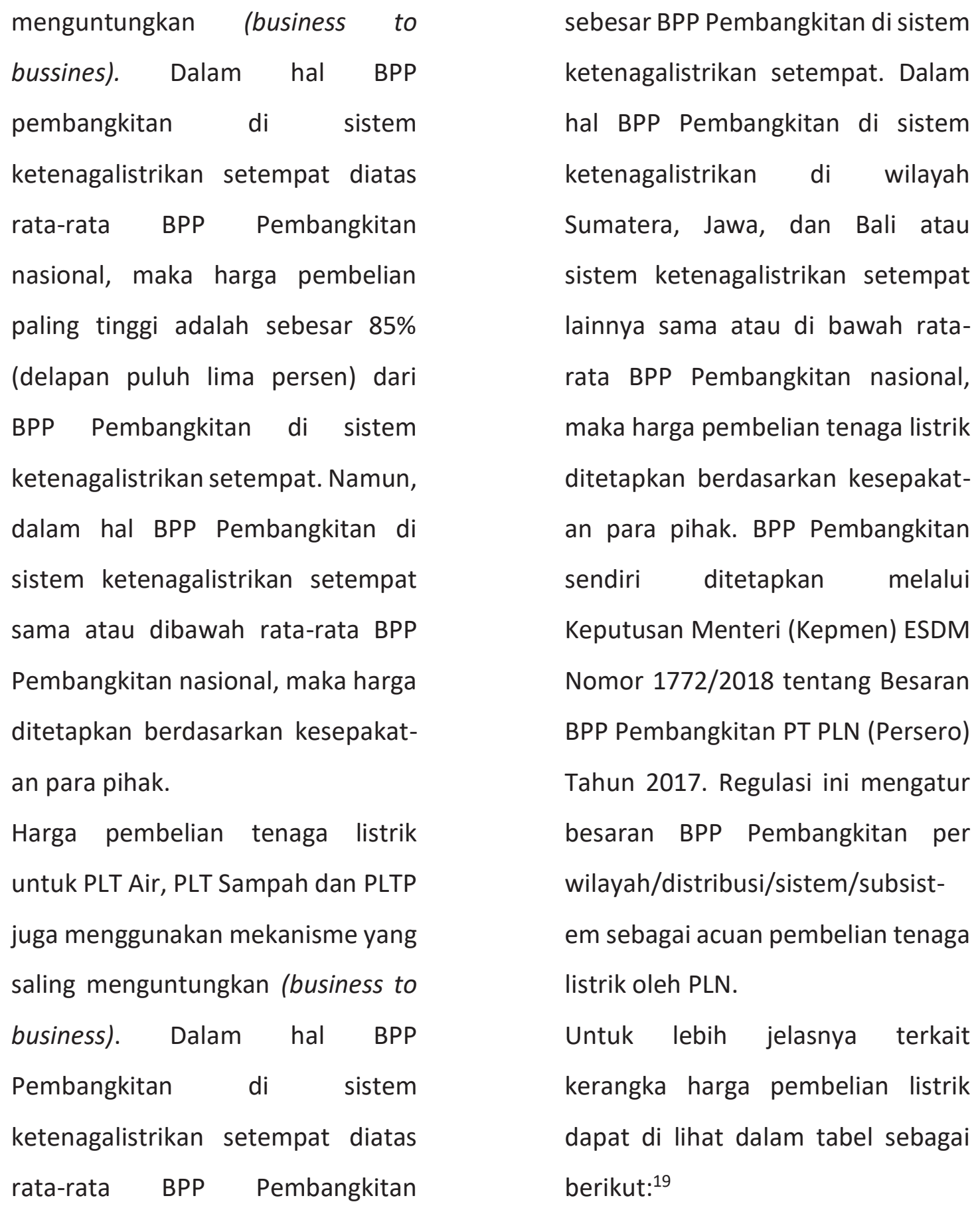

nasional, harga paling tinggi adalah

19 https://www.cnbcindonesia.com/news/20180525141148-4-16595/menimbang-aturan-baru-terkaitskema-harga-listrik-ebt, diakses pada tanggal 8 Agustus 2019 
Tabel 3. Kerangka Harga Pembelian Listrik

\begin{tabular}{|c|c|}
\hline Sumber Pembangkit Listrik & Kerangka Harga Pembelian Listrik \\
\hline \multicolumn{2}{|l|}{ Solar PV dan Angin } \\
\hline BPP lokal > rerata BPP nasional & Maksimal 85\% dari BPP lokal \\
\hline BPP lokal $\leq$ rerata BPP nasional & Ditentukan lewat kesepakatan PLN dan IPP \\
\hline \multicolumn{2}{|l|}{ Hidro } \\
\hline BPP lokal > rerata BPP nasional & Maksimal 85\% dari BPP lokal \\
\hline BPP lokal $\leq$ rerata BPP nasional & Ditentukan lewat kesepakatan PLN dan IPP \\
\hline \multicolumn{2}{|l|}{ Biomassa dan Biogas } \\
\hline BPP lokal > rerata BPP nasional & Maksimal 85\% dari BPP lokal \\
\hline BPP lokal $\leq$ rerata BPP nasional & Ditentukan lewat kesepakatan PLN dan IPP \\
\hline \multicolumn{2}{|l|}{ Sampah Perkotaan dan Panas Bumi } \\
\hline BPP lokal > rerata BPP nasional & Maksimal 85\% dari BPP lokal \\
\hline BPP lokal $\leq$ rerata BPP nasional & Ditentukan lewat kesepakatan PLN dan IPP \\
\hline \multicolumn{2}{|c|}{ Air Laut (belum diregulasi di Permen ESDM 12/2017) } \\
\hline BPP lokal > rerata BPP nasional & Maksimal 85\% dari BPP lokal \\
\hline BPP lokal $\leq$ rerata BPP nasional & Ditentukan lewat kesepakatan PLN dan IPP \\
\hline
\end{tabular}

Sumber: Permen ESDM 50/2017 (2017)

Terkait penentuan harga BPP oleh pemerintah ini dalam implementasinya banyak dikeluhkan para pelaku usaha. Salah satu penyebabnya adalah bahwa meskipun tren harga EBT di luar negeri semakin murah, tetapi karena di Indonesia terdapat kewajiban porsi Tingkat Kandungan Dalam Negeri (TKDN) yang besar sebagaimana diatur dalam Pasal 15 Permen ESDM 50/2017, hal ini menjadikan harga EBT masih mahal. Ketika pendapatan pembangkit EBT tergantung dengan BPP yang ditetapkan PLN sementara BPP itu sendiri tidak sesuai dengan komponen biaya yang dikeluarkan, maka hal ini menjadikan proyek pembangkit EBT tidak feasible dan bankable.

Selain persoalan BPP, di beberapa tempat masih dimungkinkan untuk terjadinya negosiasi yang dilakukan oleh para pihak. Hal ini dimungkinkan dalam Permen 50/2017 dengan kondisi tertentu. Namun ini juga menimbulkan ketidakpastian hukum dan ketidakadilan, sebab selama dalam klausul aturan pemerintah masih ada kata "negosiasi", ini akan menimbulkan ketidakpastian termasuk bagi PLN sendiri sebab apabila PLN membeli listrik yang bahkan hanya lebih mahal 5-10 rupiah saja, ini dapat menimbulkan kerugian 
keuangan bagi Negara. Selain itu, negosiasi ini juga membuat pelaku usaha menjadi khawatir. Alternatif solusi terhadap persoalan BPP antara lain melalui skema Feed in Tarif (selanjutnya disebut FIT). Skema ini pernah digunakan pada kebijakan sebelum penentuan BPP pada Permen 50/2017. Menurut penelitian, ditemukan bahwa harga pembelian listrik untuk pembangkit EBT berdasarkan BPP saat ini memang lebih rendah jika dibandingkan dengan pembelian sistem FIT. Hal ini memang menimbulkan dualisme persoalan. Jika menggunakan skema FIT memang sangat menguntungkan bagi pengembang EBT swasta karena memberikan margin keuntungan yang sangat besar, namun di lain pihak secara bersamaan merugikan pemerintah dan PLN selaku pihak pembeli listrik. Tingginya harga beli tersebut membuat alokasi pembelian listrik oleh PLN menjadi mahal, sehingga berujung pada kebutuhan untuk membebankan listrik mahal tersebut kepada konsumen atau pilihan lain, membebankannya kepada Negara yang memberikan subsidi listrik ke PLN. Alokasi subsidi yang semestinya bisa digunakan untuk membiayai program lain yang memberikan manfaat langsung bagi rakyat mau tidak mau akan tersedot untuk subsidi listrik jika PLN dihadapkan pada harga beli mahal berbasis FIT tersebut. Ini yang tidak sesuai dengan agenda Nawacita bidang ekonomi yaitu mewujudkan kemandirian ekonomi dengan menggerakkan sektor strategis ekonomi domestik, dimana salah satunya adalah mewujudkan kedaulatan energi. Hal ini bertolak belakang sebab dengan feed in tariff subsidi tersebut dinikmati oleh perusahaan-perusahaan swasta dan bukan untuk menyasar pengguna tingkat akhir (end user) yaitu rakyat. ${ }^{20}$

2. Terkait skema Membangun, Memiliki, Mengoperasikan, dan Mengalihkan (Build, Own, Operate, and Transfer/BOOT) BOOT adalah pembiayaan yang

20 Ibid. 
dilakukan oleh pihak ketiga (swasta)

maupun mendesain, membangun, dan pengelolaan fasilitas

infrastruktur untuk periode tertentu sesuai konsesi yang disepakati.

Pihak swasta ini bertanggungjawab dalam melakukan pembiayaan, utamanya pada proyen baru (greenfield). Untuk skema BOOT lamanya waktu konsesi telah ditentukan yaitu 30 (tigapuluh) tahun, dan selama periode konsesi proyek tersebut dimiliki oleh pihak swasta dan dikembalikan kepada pemerintah di akhir konsesi. ${ }^{21}$

Kebijakan skema BOOT ini dinilai merugikan oleh Pengusaha. Potensi kerugian tersebut timbul karena melalui skema BOOT, PT PLN (Persero) dapat mengambil alih aset pengembang. Menjadi persoalan ketika asset berupa tanah ikut di depresiasi. Pelaku usaha menilai bahwa seharusnya di skema BOOT, ketika asset akan diserahkan, seharusnya ada nilai penggantian yang diberikan oleh Negara karena pada saat itu tanahnya masih memiliki nilai. Apalagi investor sudah menanamkan modal yang besar terhadap proyek ini, dan tanahnya juga milik investor. Ini menjadi persoalan di bidang hukum pertanahan juga. Menurut Prof Maria Soemarjono, ${ }^{22}$ jika tanahnya adalah milik investor maka sangat tidak fair jika tanahnya juga diserahkan kepada pemerintah. Namun jika skema BOOT nya menggunakan tanah milik Pemerintah, memang sudah seharusnya dikembalikan ke pemerintah setelah masa konsesi berakhir. Hal ini perlu ditegaskan dulu persoalan pengalihan asset, apakah termasuk tanah ataukah hanya asset mesin pembangkitnya saja. Hal ini belum terlihat dari regulasi Pemerintah.

Kesulitan pengembang juga dialami ketika tahap financial closing, sebab financial closing dipengaruhi oleh Skema BOOT dan Tarif. Banyak yang tidak mencapai financial closing

21 Bahtiar Rifai, Kendala Implementasi Kerjsasama Pemerintah Swasta (KPS) Kelistrikan dan Kebutuhan Perbaikan Kebijakan, Jurnal Ekonomi dan Pembangunan Vol. 24, No. 1, Tahun 2016, hlm. 55

22 Maria Soemarjono, Op., Cit., Rapat Tim Pakar SDALH. 


\begin{abstract}
karena proyeknya tidak bankable, sementara bankability tersebut dipengaruhi oleh perkiraan penjualan listrik. Menurut data sebanyak 68 PPA EBT terkendala jaminan bank. Sebagian besar penandatanganan PPA tahun 2017 tidak bisa melakukan kontrak karena belum menyerahkan jaminan ke Bank. Alasan tidak terjadinya financial closing adalah karena skema BOOT pada Permen ESDM 50/2017 tidak bisa diterima oleh Bank untuk memberikan pendanaan karena asset yang dijaminkan bukan merupakan milik pengembang. Ketidakpastian hukum ini menjadi persoalan bagi para pelaku usaha dalam pengembangan EBT sebab PPA yang ditandatangani baru akan berlaku secara efektif setelah pengembang menyerahkan jaminan pelaksanaan dan menyepakati bersama tanggal efektif dengan PLN wilayah. ${ }^{23}$
\end{abstract}

3. Terkait Mekanisme pemilihan langsung dalam bisnis Energi Terbarukan
Permasalahan dalam pemilihan langsung adalah bagaimana mengatur agar tetap ada rasa keadilan (fairness) bagi Pemerintah dalam hal ini PT PLN (Persero). Harus ada mekanisme pengawasan yang bisa mengawasi pasar monopoli dengan institusi yang dominan di pasar ini, misalnya dulu ada Badan Pengawasan Listrik (Bapepal) yang menjalankan fungsi pengawasan.

\section{PENUTUP}

Pemerintah telah menyusun rencana pengelolaan energi untuk memenuhi kebutuhan energi nasional yang berdasarkan kebijakan pengelolaan energi jangka panjang melalui Undang-Undang Nomor 30 Tahun 2007 tentang Energi. Pada Sektor ketenagalistrikan, listrik merupakan sumber daya energi yang strategis dan sangat penting bagi hajat hidup rakyat banyak. Pemerintah telah berkomitmen bahwa EBT akan terus dikembangkan untuk menjamin ketahanan energi di Indonesia serta memenuhi permintaan listrik yang kian bertambah. Pemerintah menetapkan

23 http://news.metrotvnews.com/read/2018/02/15/832136/sebanyak-68-ppa-ebt-terkendalajaminan-bank, diakses pada tanggal 15 September 2019 
target $23 \%$ porsi energi bersih dalam bauran energi nasional di tahun 2025 dan 31\% pada tahun 2030 melalui Kebijakan Energi Nasional (KEN) dan Rencana Umum Energi Nasional (RUEN). Namun dalam implementasinya masih terdapat banyak persoalan.

Faktor-faktor penyebab pertumbuhan pengelolaan EBT di sektor ketenagalistrikan belum optimal antara lain: (a) belum maksimalnya pelaksanaan kebijakan harga, (b) ketidakjelasan subsidi EBT pada sisi pembeli (off-taker), (c) regulasi yang belum dapat menarik investasi, (d) belum adanya insentif pemanfaatan EBT, (e) minimnya ketersediaan instrumen pembiayaan yang sesuai dengan kebutuhan investasi, (f) proses perizinan yang rumit dan memakan waktu yang lama, dan (g) permasalahan lahan dan tata ruang.

Evaluasi kebijakan peraturan perundang-undangan terkait EBT di sektor ketenagalistrikan antara lain (1) masih adanya perbedaan penafsiran dalan makna “dikuasai negara" pada pasal 4 UU Energi. Bahwa makna "dikuasai oleh Negara" tidak perlu dipertentangan kata per kata, sebab konsepnya adalah menyeluruh. Hal ini sudah jelas di dalam putusan MK Nomor 36/PUU-X/20012 terkait putusan dalam uji materiil UU Nomor 22 Tahun 2001 tentang Minyak dan Gas Bumi. Penguasaan Negara sebagaimana dimaksud dalam Putusan MK yang terdiri dari 5 (lima) konsep frasa yaitu kebijakan, pengurusan, pengaturan, pengelolaan dan pengawasan adalah kesemuanya. Pelaksanaan terhadap 1 frasa misalnya melaksanakan pengaturan, maka itu juga sebagai bentuk penguasaan Negara; (2) Terkait skema penentuan biaya pokok penjualan (BPP) penjualan listrik energi terbarukan oleh Pemerintah melalui Permen ESDM 50/2017 yang masih banyak dikeluhkan para pelaku usaha; (3) Terkait skema membangun, Memiliki, Mengoperasikan, dan Mengalihkan (Build, Own, Operate, and Transfer/BOOT); (4) Terkait mekanisme pemilihan langsung dalam bisnis EBT.

Beberapa alternatif strategi pengembangan EBT di sektor ketenagalistrikan antara lain: (1) Potensi energi terbarukan (matahari, angin, bioenergi, panas bumi) yang dimiliki Indonesia perlu dimanfaatkan secara maksimal untuk menambah kapasitas terpasang pembangkit listrik, rasio elektrifikasi dan penurunan emisi gas rumah kaca sesuai dengan PP Nomor 79 Tahun 2014 tentang Kebijakan Energi 
Indonesia; (2) Menemukan titik temu harga operasional untuk membangun antara kebijakan BPP menurut Permen pembangkitan energi terbarukan; (5) ESDM 50/2017 dengan keinginan para Pemerintah pusat dan pemerintah daerah, pengembang untuk kembali pada skema saling bekerjasama secara nyata untuk Feed in Tariff sehingga pengembangan EBT pengembangan di bidang EBT tanpa dapat lebih optimal; (3) Pembebasan pajak mengedepankan ego sektoral; (6) Merevisi impor peralatan energi terbarukan dan Pasal 4 UU Nomor 30 tahun 2007 tentang mendorong produsen peralatan energi Energi terkait konsep "Hak menguasai terbarukan lokal melalui pembebasan pajak Negara" terhadap sektor ketenagalistrikan dan dukungan keuangan secara langsung; yang bersumber dari EBT; (7) Sitem (4) Perlu adanya dukungan berupa pengawasan yang optimal dalam kebijakan bantuan investasi dari implementasi pemilihan langsung dalam pemerintah sekitar 20-30 \% untuk pengembangan pengembangan EBT di menggairahkan pembangunan energi sektor ketenagalistrikan.

terbarukan di tengah masih mahalnya 


\section{DAFTAR PUSTAKA}

\section{A. Buku}

Agus Sugiyono, Permasalahan dan Kebijakan Energi Saat Ini, dalam Prosiding Peluncuran Buku Outlook Energi Indonesia 2014 \& Seminar Bersama BPPT dan BKK-PII, Jakarta, Tahun 2015

Badan Pembinaan Hukum Nasional, Analisis dan Evaluasi Hukum Dalam Rangka Kedaulatan Energi, Laporan Akhir Tim Pokja, Jakarta, 2016

Bahtiar Rifai, Kendala Implementasi Kerjsasama Pemerintah Swasta (KPS) Kelistrikan dan Kebutuhan Perbaikan Kebijakan, Jurnal Ekonomi dan Pembangunan Vol. 24, No. 1, Tahun 2016

Muhammad AS Hikam: Ketahanan Energi Indonesia 2015-2025 Tantangan dan Harapan (Jakarta: CV. Rumah Buku, 2014)

\section{B. Makalah}

Agus Sugiyono, Permasalahan dan Kebijakan Energi Saat Ini, dalam Prosiding Peluncuran Buku Outlook Energi Indonesia 2014 \& Seminar Bersama BPPT dan BKK-PII, Jakarta, Tahun 2015

Mailinda Eka Yuniza, Kajian Distribusi Kewenangan Dalam Tata Kelola Sektor Energi Terbarukan, disampaikan pada Diskusi Terbatas yang diselenggarakan oleh World Resources Indonesia (WRI, di Jakarta, tanggal 18 April 2018

Maria Soemardjono, Rapat Tim Pakar Bidang SDALH, diselenggarakan di Jakarta pada tanggal 2 Agustus 2018.

Jimly Asshidiqie, Makna Dikuasai Negara dalam Pasal 33 UUDNRI Tahun 1945, disampaikan dalam Diskusi Terbatas Reformasi Hukum Tata Kelola Sektor Energi Terbarukan, yang diselenggarakan oleh Badan Pembinaan Hukum Nasional dan World Resources Indonesia, di Jakarta, pada tanggal 8 Agustus 2018.

\section{Peraturan Perundang-Undangan}

Indonesia, Undang-Undang Nomor 30 Tahun 2007 tentang energi, diundangkan di Jakarta pada tanggal 10 Agustus 2007, LNRI Tahun 2009 Nomor 133, TLNRI Nomor 4746.

Indonesia, Undang-Undang Nomor 30 Tahun 2009 tentang energi, diundangkan di Jakarta pada tanggal 23 September 2009, LNRI Tahun 2007 Nomor 96, TLNRI Nomor 5052.

Mahkamah Konstitusi, Putusan MK Nomor 36/PUU-X/2002 terkait putusan dalam uji materiil UU Nomor 22 Tahun 2001 tentang Minyak dan Gas Bumi, diputus pada tanggal 13 Nopember 2012 di Jakarta. 
Indonesia Permen ESDM Nomor 50 Tahun 2017 tentang Pemanfaatan Sumber Energi Terbarukan Untuk Penyediaan Tenaga Listrik, diundangkan di Jakarta pada tanggal 8 Agustus 2017, Berita Negara RI Atahun 2017 Nomor 1107.

\section{Internet}

https://ekonomi.kompas.com/read/2018/01/16/090100826/melihat-pltb-sidrap pembangkit-tenaga-angin-pertama-di-indonesia

https://ekonomi.kompas.com/read/2017/11/17/083000026/bappenas-perkembangan-energi-terbarukan-hadapi-banyak-tantangan

https://www.cnbcindonesia.com/news/20180525141148-4-16595/menimbang-aturanbaru-terkait-skema-harga-listrik-ebt

http://news.metrotvnews.com/read/2018/02/15/832136/sebanyak-68-ppa-ebtterkendala-jaminan-bank 


\section{BIODATA PENULIS}

Nunuk Febriananingsih, S.H., M.H. Kepala Sub Bidang Sumber Daya Alam dan Lingkungan Hidup I pada Pusat Analisa dan Evaluasi Hukum Nasional, Badan Pembinaan Hukum Nasional Kementerian Hukum Nasional. Pendidikan Sarjana (S1) didapat dari Fakultas Hukum Universitas Indonesia Jakarta. Selanjutnya yang bersangkutan menyelesaikan pendidikan Magister Hukum (S2) Fakultas Hukum pada Universitas Padjajaran Bandung. Nunuk selalu menjaga hubungan yang harmonis antara keahliannya dalam bidang hukum dan kebutuhan masyarakat. Dia mengikuti minatnya di bidang hukum, setelah menghabiskan masa sarjana di bidang hukum ekonomi yang dilakukan di Universitas Indonesia. Dia melanjutkan studinya melalui program beasiswa Kementerian Hukum dan Hak Asasi Manusia di Universitas Padjadjaran Bandung Indonesia dalam hukum tata negara. Setelah 4 tahun bekerja untuk Kepala Sub Bidang Penegakan Hukum di Pusat Penelitian dan Pengembangan Sistem Hukum Nasional, Nunuk pindah ke Kepala Sub Bagian Sumber Daya Alam I yang membawahi bidang hukum Energi Sumber Daya Mineral, Pertambangan, Lingkungan Hidup, Kehutanan, Perkebunan, Pertanahan dan Penataan Ruang, di Lingkungan di Pusat Analisis dan Evaluasi Hukum Nasional. Pendidikannya yang berbeda dan pengalamannya yang luas telah memberinya keuntungan yang cukup dalam program nasional pemerintah dalam rangka penataan regulasi terutama di sektor sumber daya alam dan lingkungan. Lebih lanjut, ia memiliki pengalaman dalam hukum penelitian dan pengembangan, analisis dan evaluasi hukum bidang Sumber Daya Alam, dan perancangan hukum. 